\title{
Compensation, Communication Systems and Job Satisfaction
}

\author{
Paulus Robert Tuerah* \\ Study Program Social Science \\ Education \\ Faculty of Social Science \\ Universitas Negeri Manado \\ Manado, Sulawesi Utara \\ paulustuerah@unima.ac.id
}

\author{
Theodorus Pangalila \\ Pancasila and Civic Education \\ Department \\ Faculty of Social Science \\ Universitas Negeri Manado \\ Tondano, Indonesia \\ theopangalila@unima.ac.id
}

\begin{abstract}
The purpose of this study is to look at the relationship between communication systems with teacher job satisfaction in Tomohon City. The population unit in this study was junior high school teachers in Tomohon City, totaling 397 teachers by taking a sample of 186 for an error rate of $5 \%$. The research method used is a quantitative method with a survey research approach. Next, researchers examine existing hypotheses and explain the relationships between variables. The data obtained were analyzed through the application of correlation statistics and regression tests to examine the relationships and influences between the variables studied. The conclusions of this study: (1) Teacher compensation and job satisfaction have a significant and linear relationship with job satisfaction (2) Communication systems and job satisfaction have a significant and linear relationship. (3) There is a significant and linear relationship between the compensation variable and the communication system together with job satisfaction.
\end{abstract}

Keywords: Compensation, Communication Systems, Job Satisfaction

\section{INTRODUCTION}

In a communication system, researchers explore how language understanding, methods, tools, or perceptions of teachers in their relationships with their students, fellow teachers and superiors. Quite often it happens that teachers are not able to understand the delinquency that is always done by their students. On the other hand, misunderstanding or the lack of synergy between fellow teachers in behaving towards children is no longer a new thing. The existence of policies from superiors (School Principals, Foundations or Education Offices) which are still considered biased bring a bad precedent to the communication system. For example, there is a salary receipt past the specified date, without clear communication. Or if a supervisor makes a mutation, without a study that can be accounted for,

In a business organization engaged in services, Communication [1] is an important thing between a person and information. Not only on the position, either a manager or employee has the information needed to run the job. Communication between all members within an organization is very important in determining success.

If job satisfaction is not met, then what will happen is a feeling of being dissatisfied. This dissatisfaction if the solution is not found or is left on for a long time, it can ignite a disappointment, demonstration and even rebellion.
In fact, Junior High School teachers in Tomohon City do not have a maximum communication system and do not get the expected compensation. The existence of promising compensation for teachers, but in its implementation is still far from expectations, making the job satisfaction of teachers decreased. Likewise, the presence of non-smooth communication has reduced the level of satisfaction of teachers. These two things affect the level of job satisfaction of teachers in general, and junior high school teachers in Tomohon City in particular.

Kambey [2] revealed several definitions of communication according to some experts as follows: (a) Louis Fordale: Communication is a process by which a system is formed, maintained and distinguished by sharing signals that are operated through rules (Communication is the process by which a system is established, maintained, and altered by means of shared signals that operate according to rules) (b) Koontz and Weihrich: We define communication as the transfer of information from the sender to the recipient with the understanding that the information is understood by the recipient (c) William $J$. Seller: Communication is a process by which verbal and nonverbal symbols are sent, received and given meaning, (d) Sukanto and Handoko: Communication is an effort to encourage others to interpret opinions as what is desired by those who have these opinions, Communication can be used to achieve various objectives. According to Muhyadi [3] the most important function of communication is to convey information. According to Koontz and Weihrich, the broadest purpose of information is to effect change. And specifically, the purpose of communication is to: (a.)Establish/ enforce and disseminate organizational goals., (b) Develop plans in order to achieve them, (c) Organize people and other resources as effectively and efficiently as possible, (d) Select, develop and assess members of the organization. (e) Leading, promoting, promoting solidarity between teachers and creating a climate conducive for people to participate and (f) Control performance.

According to Tuerah [4], Communication system is One factor that must to do with teacher performance, and the indications can be seen through various facts such as the teaching teacher who is not trying to perfect teaching. This happens because of the lack of guidance, direction, and supervision from the principal of the teaching and learning process. The teacher also does not follow and pay attention to what should be the task according to competence, namely 
professional, personality, pedagogic and social. Interpersonal communication [5] is a communication that occurs between two people who have a relationship, people who in one way "connected". Interpersonal communication is also a process of exchanging information between a person with at least one other person or usually between two people who can be directly known the feedback. As more people involved in communication, leads to the increase of the perspective of people in communication events, the more complex communication will becomes.

There are various definitions of communication put forward from each foreign perspective. According to Hornby [6], the term communication describes three elements as follows: (a) Communication activities (the act of communicating), (b) Things that are communicated (that which is communicated), (c) .Communication tools: main roads, railways, telephones or telegraphs that connect radio and TV places (means of communicating: roads, railways, telephone or telegraph lines connecting places, radio and TV).

According to Cascio [7] Job satisfaction is a pleasant feeling caused by the individual's perception that his effort to complete work assignments is something that is important. R. W.. Woodman and D. Hellriegel said that [8] Job satisfaction is a positive emotional state employees wish to feel from the result of appraisal or job experience. The influential factors among others are the characteristics of the employee, type of job, working environment, and employee relations Job satisfaction [9] has a big effect to get optimal work result. When a person is satisfied with his/her job, that person will work hard by using all the ability to complete the job

Therefore job satisfaction [10] is the evaluation of individuals on their performance in the context of their work related to job characteristics, environmental factors and emotional experience at work. Job satisfaction reflects the feelings and attitudes of employees towards a job. The teachers' job satisfaction [11] directly affect their working enthusiasms, and indirectly affect students' learning attitudes and achievements.

The purpose of this study is to obtain an overview of the results of studies on: (a) The relationship between compensation and job satisfaction of junior high school teachers in Tomohon City, (b) 2. The relationship between communication systems with teacher job satisfaction in Tomohon City and (c). The relationship between compensation and communication systems together with the job satisfaction of junior high school teachers in Tomohon City.

\section{RESEARCH METHODS}

The population unit in this study was junior high school teachers in Tomohon City, totaling 397 teachers by taking a sample of 186 for an error rate of $5 \%$. The research method used is a quantitative method with a survey research approach.The researcher designed the research in order to test the relationship between the independent variable $(\mathrm{X})$ and the dependent variable (Y). The independent variables in this study consisted of two variables, namely compensation $\left(\mathrm{X}_{1}\right)$ and communication system $\left(\mathrm{X}_{2}\right)$, while the dependent variable was teacher job satisfaction (Y). To analyze the significance or strength of the relationship between variables in this study, researchers used the product moment correlation formula from Pearson, multiple correlation, simple regression and multiple regression.

The research method used is a quantitative method with a survey research approach. This method is carried out by researchers in one population unit. The data studied is data taken from the population. Through this method, researchers test existing hypotheses and explain the relationships that exist between variables. The data obtained were analyzed through the application of correlation statistics and regression tests because it examined the relationships and influences between the variables studied and measured the level of relationship between each variable.

The data in this study were obtained by using a statement distribution (questionnaire) technique. The questionnaire distributed was related to the primary data measured, namely by using two independent variables (compensation and communication systems) and one dependent variable (teacher job satisfaction).

The questionnaire used as contained in appendix 3 is a questionnaire that was tested on 30 respondents who were not part of the research sample. The questionnaire distributed to respondents contained a number of statements chosen by respondents using a Likert scale. The statements chosen by respondents are based on characteristics that are indicators of the three types of research variables namely compensation indicators, communication systems and teacher job satisfaction.

\section{RESULT AND DISCUSSION}

\section{A. Data Description}

Descriptions for the Job Satisfaction Variable (Y), Compensation $\left(\mathrm{X}_{1}\right)$, Communication System $\left(\mathrm{X}_{2}\right)$ can be seen in table 1 as follows:

Table 1: Data Description

\begin{tabular}{|c|c|c|c|}
\hline Variabel & Mean & Variance & Std. Deviation \\
\hline $\mathrm{X}_{1}$ & 91.41 & 55.390 & 7.442 \\
\hline $\mathrm{X}_{2}$ & 95.79 & 60.588 & 7.783 \\
\hline $\mathrm{Y}$ & 98.67 & 46.286 & 6.803 \\
\hline
\end{tabular}

\section{B. Model}

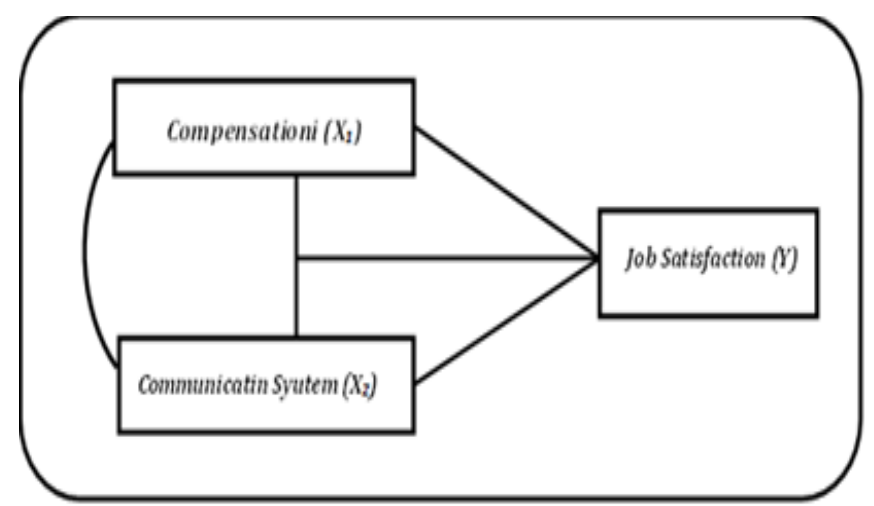




\section{Normality Test for Estimated Error}

Based on the calculation of the normality test conducted on data from 186 respondents including variables Job Satisfaction Variables (Y), Compensation $\left(\mathrm{X}_{1}\right)$, Communication Systems $\left(\mathrm{X}_{2}\right)$ it turns out the null hypothesis is accepted that the population is normally distributed. Thus it can be concluded that all data from each variable is normally distributed. The summary of the normality test can be seen in Table 2 as follows:

Table 2: Summary of Estimated Error Test Normality Test Results

\begin{tabular}{|l|c|c|l|}
\hline \multicolumn{1}{|c|}{ Variables } & $\begin{array}{c}\text { Kolmogorov- } \\
\text { Smirnov }\end{array}$ & $\begin{array}{c}\text { Shapiro- } \\
\text { Wilk }\end{array}$ & Remarks \\
\hline Compensation & $0,030>0,05$ & $\begin{array}{c}0.030> \\
0,05\end{array}$ & Normal \\
\hline Communication & $0.200>0,05$ & $\begin{array}{c}0,200> \\
0,05\end{array}$ & Normal \\
System & & $0,037>$ & Normal \\
\hline Job Satisfaction & $0.037>0,05$ & 0,05 & \\
\hline
\end{tabular}

\section{Test of Significance and Linearity}

$$
\text { ANOVA }
$$

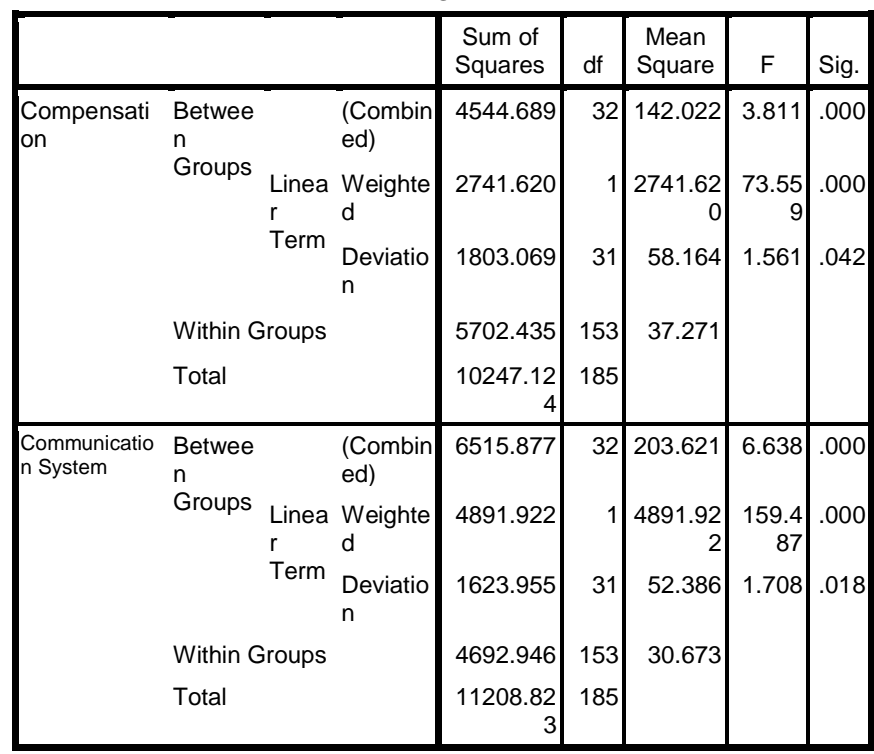

Based on the results of calculations with the SPSS program, the value of $r$ (propability value/ critical value) compensation variable is smaller than the $\alpha$ level used. Namely the value of $r=0,000 \leq \alpha(0.05)=186-1=0.148$ and the communication system variable is $r=0,000 \alpha(0.05)$ $=186-1=0.148$, so $\mathrm{H}_{0}$ is rejected, meaning the compensation and system variables linear patterned communication with job satisfaction variable.

\section{Hypothesis Testing and Discussion The Effect of Compensation on Job Satisfaction}

Based on the Summary Model table, $\mathrm{R}=0.517$ is called the coefficient of determination, which means $51.7 \%$ of the compensation variable contribution to job satisfaction. The smaller the number $\mathrm{R}$ the weaker the relationship between the two variables. So compensation has contributed to the performance of $51.7 \%$.

Anova linear regression results obtained $F_{\text {count }} 67.21$ $>\mathrm{F}_{\text {table }}$ then $\mathrm{H}_{0}$ is rejected. Because it is said that if $\mathrm{F}_{\text {count }}>$ $\mathrm{F}_{\text {table }}$ then $\mathrm{Ho}$ is rejected. Thus it is evident that compensation significantly influences job satisfaction. This means that the relationship between the two variables is very strong. Positive correlation shows that the relationship between compensation and job satisfaction is unidirectional. That is, if the implementation of compensation increases, job satisfaction will increase as well. The results of testing hypothesis 1 shows that there is a significant relationship between the compensation system and job satisfaction. This means that the compensation perceived by the employees has influenced and has a relationship to the job satisfaction of the junior high school teachers in Tomohon City. By giving compensation, both material and non-material, it causes a great job satisfaction of the teachers, so they are able to appreciate and be proud of their profession as a teacher. In other words, the factor of job satisfaction is related to meeting the needs of teachers who are carried out through the provision of compensation.

According to Ferryal Abadi [12] if the company gives incentives to the employee with high achievement in his job, and allowances, it can support employee's work activities, and employee will be praised. So that [13] if the compensation received by teachers is as they expected, it will increase the teacher's job satisfaction.

\section{Effect of Communication Systems on Job Satisfaction}

Based on the Summary Model table, there is $\mathrm{R}=0.661$ which is called the coefficient of determination which means $66.1 \%$ of the contribution of the communication system variable to job satisfaction. The smaller the number $\mathrm{R}$ the weaker the relationship between the two variables. So the communication system has a contribution to the performance of $51.7 \%$.

Anova linear regression results obtained Fcount 142.49> $\mathrm{F}_{\text {table }}$ then $\mathrm{H}_{0}$ is rejected. Because it is said that if $\mathrm{F}_{\text {count }}>\mathrm{F}_{\text {table }}$ then $\mathrm{Ho}$ is rejected. Thus it is evident that compensation significantly influences job satisfaction.

Based on the results of testing this hypothesis, there is a significant relationship between the communication system and job satisfaction of junior high school teachers in Tomohon City. This means that good communication also gives a positive influence on job satisfaction of teachers. The existence of smooth communication in connection with the work of teachers, making teachers understand and understand their work. As a result they are able to carry out their duties properly. Thus this affects their job satisfaction. These findings support the opinion of experts who state, the general purpose of the communication system is to assist leaders in making the right decisions.

Ccommunication [14] is one of key factors enhancing employees to satisfy their job. There is positive relationship between internal communication and job satisfaction. It also affected communication satisfacion, and organizational commitment

The Effect of Compensation and Communication System on Job Satisfaction 


\section{Correlations}

\begin{tabular}{l|r|r|r|}
\hline & Compensationi & Communication System & Job Satisfaction \\
\hline Pearson & 1 & $.484^{*}$ & $.517^{*}$ \\
Correlation & & .000 & .000 \\
Sig. (2-tailed) & 186 & 186 & 186 \\
$\mathrm{~N}$ & $.484^{* *}$ & 1 & $.661^{*}$ \\
\hline Pearson & & & \\
Correlation & .000 & 186 & .000 \\
Sig. (2-tailed) & 186 & $.661^{*}$ & 186 \\
$\mathrm{~N}$ & $.517^{* *}$ & .000 & 1 \\
\hline Pearson & & 186 & \\
Correlation & .000 & 186 & \\
Sig. (2-tailed) & & & \\
$\mathrm{N}$ & & & \\
\hline
\end{tabular}

${ }^{* *}$. Correlation is significant at the 0.01 level (2-tailed).

Model Summary

\begin{tabular}{|c|c|c|c|c|c|c|c|c|c|}
\hline \multirow[b]{2}{*}{ Model } & \multirow[b]{2}{*}{$\mathrm{R}$} & \multirow[b]{2}{*}{$\begin{array}{c}\mathrm{R} \\
\text { Square }\end{array}$} & \multirow[b]{2}{*}{$\begin{array}{c}\text { Adjusted } \\
\text { R } \\
\text { Square }\end{array}$} & \multirow[b]{2}{*}{$\begin{array}{c}\text { Std. } \\
\text { Error of } \\
\text { the } \\
\text { Estimate }\end{array}$} & \multicolumn{5}{|c|}{ Change Statistics } \\
\hline & & & & & $\begin{array}{c}\mathrm{R} \\
\text { Square } \\
\text { Change }\end{array}$ & $\begin{array}{c}\mathrm{F} \\
\text { Change }\end{array}$ & df1 & $\mathrm{df} 2$ & $\begin{array}{c}\text { Sig. F } \\
\text { Change }\end{array}$ \\
\hline 1 & $.698^{\mathrm{a}}$ & .488 & .482 & 4.89702 & .488 & 87.039 & & 183 & .000 \\
\hline
\end{tabular}

a. Predictors: (Constant), Compensation, Communication Syutem

b. Dependent Variable: Job Satisfaction

ANOVA $^{\mathrm{b}}$

\begin{tabular}{|l|r|r|r|c|c|}
\hline Model & Sum of Squares & df & Mean Square & F & Sig. \\
\hline 1 Regression & 4174.509 & 2 & 2087.254 & 87.039 & $.000^{\mathrm{a}}$ \\
Residual & 4388.486 & 183 & 23.981 & & \\
Total & 8562.995 & 185 & & & \\
\hline
\end{tabular}

a. Predictors: (Constant), Compensation, Communication System b. Dependent Variable: Job Satisfaction

\section{Coefficients $^{\mathrm{a}}$}

\begin{tabular}{|c|c|c|c|c|c|}
\hline \multirow[b]{2}{*}{ Model } & \multicolumn{2}{|c|}{$\begin{array}{l}\text { Unstandardized } \\
\text { Coefficients }\end{array}$} & \multirow{2}{*}{\begin{tabular}{c|}
$\begin{array}{c}\text { Standardized } \\
\text { Coefficients }\end{array}$ \\
Beta \\
\end{tabular}} & \multirow[b]{2}{*}{ t } & \multirow[b]{2}{*}{ Sig. } \\
\hline & $B$ & Std. Error & & & \\
\hline (Constant) & 32.238 & 5.152 & & 6.257 & .000 \\
\hline $\begin{array}{l}\text { Communication } \\
\text { System }\end{array}$ & .468 & .053 & .536 & 8.862 & .000 \\
\hline Compensation & .236 & .055 & .258 & 4.270 & .000 \\
\hline
\end{tabular}

a. Dependent Variable: Job Satisfaction

Based on the Summary Model table there is $\mathrm{R}=0.698$ which is called the coefficient of determination which means $69.8 \%$ contribution of the compensation variable and the communication system to job satisfaction. The smaller the number $\mathrm{R}$ the weaker the relationship between the two variables.

For a significant level of linear regression results obtained ANOVA $\mathrm{F}_{\text {count }} 87.039>\mathrm{F}_{\text {table }}$ then $\mathrm{H}_{0}$ is rejected. This means that the relationship between the two variables $\mathrm{X}_{1}$ and $\mathrm{X}_{2}$ with $\mathrm{Y}$ is very strong. Positive correlation shows that the relationship between compensation and communication systems together with direct job satisfaction. That is, if the implementation of compensation and communication systems increase, job satisfaction will increase as well.
Thus there is a significant relationship between compensation and communication systems on job satisfaction. This shows that receiving adequate compensation supported by a harmonious atmosphere in an open and smooth communication, has an effective influence on job satisfaction. In this case, Job satisfaction [15] has the same sense with the attitude of the worker, which describes the positive feelings toward his work, based on the evaluation of the characteristics of the job.

\section{CONCLUSION}

Based on the results of research and discussion, the following conclusions can be drawn:

1. Compensation and job satisfaction of junior high school teachers in Tomohon City have a significant and linear relationship. It shows that giving compensation, both material and non material, will increase job satisfaction.

2. Communication systems with job satisfaction have a significant and linear relationship. This shows that if the communication system runs well and effectively, it will increase job satisfaction of teachers.

3. There is a significant and linear relationship between the compensation variable and the communication system together with job satisfaction. This shows that the more effective and efficient provision of compensation coupled with the implementation of an open and smooth communication system, will cause job satisfaction of junior high school teachers in Tomohon City

Based on the results of this study it is suggested:

1. It is necessary to maintain the implementation of compensation for junior high school teachers in Tomohon City. This even needs to be improved so that junior high school teachers feel that their profession is truly valued.

2. It is necessary to maintain and maintain effective communication both between superiors and subordinates as well as between fellow teachers and also between teachers and students.

3. It always needs to be examined the level of satisfaction of junior high school teachers from year to year so that enthusiasm and motivation and performance can be further improved.

4. Similar research needs to be carried out that specializes in finding the level of significance between job satisfaction and teacher performance through both qualitative and quantitative research.

\section{ACKNOWLEDGMENT}

Deepest gratitude is delivered to the rector of Manado State University, the Dean of the Faculty of Social Science UNIMA, the Organizing Committees, and Atlantis Press Publisher.

\section{REFERENCES}

[1] V. E. Andriani, "Interpersonal Communication in Workplace Bullying," vol. 260, no. Icomacs, pp. 58-60, 2018.

[2] D.C. Kambey, Landasan Teori Administrasi/ 
Manajemen: Sebuah Intisar. Manado: Yayasan Tri Ganesha Nusantara, 2006.

[3] Muhyadi, Organisasi: Teori Struktur dan Proses. Jakarta: Depdikbud., 1989.

[4] P. R. Tuerah, "Effects of Interpersonal Communication, Work Ethic and Leadership Style towards Junior High School Teacher Performance in the City of Tomohon," vol. 383, no. Icss, pp. 676$681,2019$.

[5] J. A. Devito, Komunikasi Antar Manusia. Jakarta: Profesional Books, 1997.

[6] A. . Hornby, Oxford Advanced Learner's Dictionary of Current English. London: The English Language Book Society and Oxford University Press, 1974.

[7] W.F. and Cascio, Managing human resources. Colorado: Mc GrawHill, 2003. Colorado: Mc GrawHill, 2003.

[8] R. W.. Woodman and D. Hellriegel, Organizational Behavior. South-Western College Publishing and International Thomson Publishing Company, 1996.

[9] D. R. Ayundhasurya and F. Kurniawan, "The Influence of Organizational Communication Climate on Organizational Communication Satisfaction to Non-Profit Organization CIOFF Indonesia," vol. 41, no. Bcm 2017, pp. 140-144, 2018.

[10] R. E. Rigio, Introduction to industrial/organizational psychology. New Jersey: Pearson Prentice Hall, 2009.

[11] J. Zou, "Research on Job Satisfaction of Teachers in Private Colleges and Universities in Guangdong Province *," vol. 356, no. Cesses, pp. 907-913, 2019.

[12] F. Abadi, "Analysis on the Influence of Compensation and Leadership on Job Satisfaction and Its Effect on Job Performance," vol. 131, no. Icoi, pp. 19-24, 2017.

[13] P. R. Tuerah, "The Influence o f Principal' $s$ Leadership , Group Solidarity and Work Compensation o $\mathrm{n}$ Teachers 'Job Satisfaction in The City of Tomohon," in Advances in Social Science, Education and Humanities Research, 2018, vol. 226, no. Icss, pp. 773-777.

[14] W. Kulachai, P. Narkwatchara, P. Siripool, and K. Vilailert, "Internal communication, employee participation , job satisfaction , and employee performance," vol. 186, no. Insyma, pp. 124-128, 2018.

[15] A. Askolani and D. L. Maulid, "The Effect of Job Satisfaction and Organizational Commitment to Performance of Employees Dinas Pendidikan Kota Bandung," vol. 65, no. Icebef 2018, pp. 264-269, 2019. 